\title{
THE AIRWAY OBSTRUCTION - IMPORTANT ABRUPT CONDITION FOR PEDIATRICS
}

\section{Marek Tomaszewski ${ }^{1,2}$, Katarzyna Banakiewicz ${ }^{3}$, Krzysztof Jajko ${ }^{3}$, Roman Szypowski ${ }^{3}$, Paweł Zielińskii ${ }^{3}$, Grzegorz Zalewski ${ }^{3}$, Stanisława Spisacka ${ }^{2}$, Grażyna Olchowik ${ }^{2,4}$}

\author{
${ }^{1}$ Department of Human Anatomy, Medical University of Lublin \\ ${ }_{2}^{2}$ John Paul II State School of Higher Education in Biała Podlaska \\ ${ }^{3}$ Anatomic Group at the Chair and Department of Human Anatomy, Medical University of Lublin \\ ${ }^{4}$ Department of Biophysics, Medical University of Lublin
}

Tomaszewski M., Banakiewicz K., Jajko K., Szypowski R., Zieliński P., Zalewski G., Spisacka S., Olchowik G. (2015), The airway obstruction - important abrupt condition for pediatrics. Health Problems of Civilization, 1 (9), p. 18-22

Summary: The ability of fast response in case of increasing health problems of a child which lead directly to life-threatening situations is a necessary condition for creating opportunity of child's survival until it will be transported to intensive care unit, where it will be provided with care by a specialist. In case of healthy children the most common cause of acute respiratory failure is obstruction of upper respiratory tract. There is an enormous variety of causes of upper airway obstruction, but the most important are the result of congenital defects, acute inflammation, anaphylactic reactions, foreign body aspiration and injuries. Consequence of the hypoventilation resulting from significant impediment of airflow through the obstructed airways is impaired gas exchange in the lungs. This leads to the increasing hypoxemia ( $\mathrm{PaO} 2<60 \mathrm{mmHg}$ ) and hypercapnia $(\mathrm{PaCO} 2>45 \mathrm{mmHg}$ ). This condition is called the total respiratory failure. The persistence of hypoventilation leads to hypoxia of vital organs (heart muscle, brain), increased anaerobic metabolism, acidosis, and inevitably to cardiac arrest as a result of homeostasis disorders. Respiratory failure is defined as acute when developing suddenly and is potentially reversible. We can find such a situation in the fast-increasing stenosis of the larynx. Symptoms of severe dyspnoea occur in a short time, but can be interrupted by an effective airway patency. Acute respiratory failure is a state of direct threat to life, which is why it is crucial to give a prompt aid to the sick child. The aim of this paper is to discuss the signs and symptoms, knowledge of which is essential for rapid identification and initial differentiation of the causes of acute upper airway obstruction in children. The principles of first-aid for children with acute respiratory failure and above all the description of life-saving procedures will be presented.

Keywords: airway obstruction, hypoxemia, hypercapnia, respiratory failure

\section{Introduction - acute respiratory failure (ARF)}

One of the most common causes of ARF in previously healthy children is obstruction of the upper airways (UA). There is a huge variety of causes of obstruction of UA, but the most important ones are the result of congenital defects, acute inflammation, anaphylactic reactions, foreign body aspiration and injuries (Oleniacz 2008). Consequence of the hypoventilation resulting from significant impediment of airflow through the obstructed airways is impaired gas exchange in the lungs. This leads to the increasing hypoxemia ( $\mathrm{PaO} 2<60 \mathrm{mmHg}$ ) and hypercapnia (PaCO2> $45 \mathrm{mmHg}$ ). This condition is called the total respiratory failure (Szczeklik 2010). The persistence of hypoventilation leads to hypoxia of vital organs (heart muscle, brain), increased anaerobic metabolism, acidosis, and inevitably to cardiac arrest as a result of homeostasis disorders. Respiratory failure is defined as acute when developing suddenly and is potentially reversible. We can find such a situation in the fast-increasing stenosis of the larynx (Daniel 2006; Kwong et al. 2007). Symptoms of severe dyspnoea occur in a short time, but can be interrupted by an effective airway patency. ARF is a state of direct threat to life, for this reason it is crucial to give a prompt aid to the sick child.

\footnotetext{
Address for correspondence: Marek Tomaszewski, Pope John Paul II State School of Higher Education in Biała Podlaska, Sidorska 95/97 Street, 21-500 Biała Podlaska, e-mail: tomaszewski.marek@gmail.com, phone: (83) 3449918

Tables: 1 Figures: 0 References: 14 Full-text PDF www.hpc.edu.pl Copyright (C Pope John Paul II State School of Higher Education in Biała Podlaska, Sidorska 95/97, 21-500 Biała Podlaska Indexation: Index Copernicus, Database AGRO, ProQuest, Polish Ministry of Science and Higher Education. This is an open-access article distributed under the terms of the Creative Common Attribution Non-commercial license (http://creativecommons.org/licenses/by-nc/3.0), which permits use, distribution and reproduction in any medium, provided the original works is properly cited, the use is non-commercial and is otherwise in compliance with the license.
} 


\section{The anatomy of larynx in children}

The larynx is part of the upper respiratory tract and the voice organ. It is composed of muscles, ligaments, connective membranes and skeleton made of cartilages. Cavity of the larynx consists of three sections: the upper vestibule of the larynx, middle - middle cavity of the larynx and lower - subglottic cavity. The larynx functions as a phonatory, respiratory and defence organ. There are fundamental differences between the larynges of a new-born, an infant, a young child, and an adult human larynx. $1 \mathrm{~mm} 2$ of infant's glottis supplies $0.013 \mathrm{~m}^{2}$ of oxygen to the body surface area, while in the adult-it supplies $0.009 \mathrm{~m}^{2}$. Delivery of oxygen in the infant appears adversely and it is drastically reduced during the oedema of the mucous membrane of the larynx. Oedema of subglottic area in infants and children is a threat to life far more often than in adults. This is due to the large accumulation of connective tissue with a number of lymph vessels, which becomes readily oedema as a result of activation by irritating factors such as infection, allergy, and injury.

Table 1 shows changes in cross-section of subglottic larynx, caused by the oedema of this area depending on the age (Baker et al. 2006; Maciejewski and Torres 2007).

Table 1. Changes of subglottic area caused by oedema

\begin{tabular}{|l|l|c|c|c|}
\hline & & New-borns & Children & Adults \\
\hline Normal & Diameter of subglottis $(\mathrm{mm})$ & 4 & 8 & 14 \\
\hline & Surface of subglottis $\left(\mathrm{mm}^{2}\right)$ & 12 & 48 & 147 \\
\hline & & & & \\
\hline Result 1 mm oedema & Diameter of subglottis (mm) & 2 & 6 & 12 \\
\hline & Surface of subglottis $\left(\mathrm{mm}^{2}\right)$ & 3 & 27 & 108 \\
\hline & & & & 27 \\
\hline
\end{tabular}

The high location of the larynx and undeveloped sufficiently in the early period of life mechanisms of local and systemic immunity are conducive to the spread of viral and bacterial infections of the upper parts of the respiratory system. During the infection the inflammatory oedema occurs, that narrows significantly the airway and impairs the respiratory airflow through the throat.

\section{Causes of narrowing of the airways at the level of the larynx in children}

- Developmental disorders of the larynx (Bailey 2003, Baker et al. 2006, Chmielik et al. 2003, Daniel 2006, Yuen et al. 2006):

- Congenital laryngomalacia is the most common cause of stridor and exhaust dyspnoea in infants - laryngomalacia cases represent $60 \%$ of congenital anomalies of the larynx. Symptoms appear at third week of age and disappear about the 18th month of age. The essence of the disease is collapse of slender cartilage and fibrous parts during inspiration to the interior of the larynx. Most cases of congenital laryngomalacia are mild and do not require treatment. In about $10 \%$ of cases Laryngomalacia is severe, with significant respiratory problems and requires surgical treatment including tracheostomy.

- Congenital subglottic stenosis is about $10-12 \%$ of congenital larynx defects. Small and medium-sized stenosis may not be symptomatic until the infection of the upper respiratory tract, when even a slight swelling causes severe subglottic laryngitis.

- Subglottis haemangioma is a congenital tumour occurring in the area of subglottis and trachea. It can be life-threatening due to the location at the narrowest point of the respiratory tracks. Some children require implementation and maintenance of a tracheotomy until involution of haemangioma.

- Airway patency disorders can also result from other less frequent birth defects such as: total laryngeal atresia, fins, cysts and tumours.

- Paralysis of the vocal folds (Daniel 2006)

- Inspiratory stridor and expiration dyspnoea is observed in bilateral palsy which is often accompanied by defects of CNS such as Arnold-Chiari syndrome, hydrocephalus, meningocerebral hernia and others. Dysphagia with aspiration of food into the airways, which is an additional risk, appears in children with bilateral vocal cord paralysis. The severity of dyspnoea in these patients may require intubation or tracheostomy. 
- $\quad$ Acute inflammation of the larynx (Szenborn et al. 2004):

- Laryngitis occurs seasonally, mainly in the autumn-winter period and is a significant clinical problem.

- Szenborn et al. in the conclusions to their study involving 632 children hospitalized with symptoms of acute laryngeal dyspnoea pay special attention to the two morbid entities. The first is the subglottic laryngitis, which was diagnosed in over $75 \%$ of hospitalized children. The second is a rare cause $3 \%$ of hospitalizations) - the acute inflammation of the epiglottis, but with the most serious prognosis.

- Subglottis laryngitis is a disease which due to narrowing of the airway may be a threat to the life of a small child. The disease is frequent in childhood, and primarily concerned with children between third month of life and three years old. The boys get sick twice as often as girls. Etiological factor are viruses. The classic symptoms appear suddenly at night in a child previously healthy with normal body temperature or the slight fever state. The disease manifests itself in barking cough, inspiratory-expiratory stridor and inspiratory differently severe dyspnoea.

- Acute epiglottitis inflammation is rapidly coused disease in which inflammatory oedema of the epiglottis occurs and significantly impairs the patency of the larynx. Etiologic factor is mostly Haemophilus influenzae type B. Predominantly, children between 2 and 7 years of age get sick. Classic symptoms include severe sore throat, dysphagia, high fever and rapidly growing inspiratory dyspnoea. The disease develops within a few hours leading to immediate danger of life by suffocation or the development of sepsis. Examination of the throat may intensify dyspnoea. In many cases require intubation and treatment in the ICU.

- Foreign bodies in the larynx (Szreter 2011):

- Aspiration of foreign body is the most common cause of respiratory distress in young children and is one of the major causes of morbidity and mortality in this age group. The problem of foreign body aspiration affects the most children less than three years of age who put various objects into their mouth and in this way learn about the world. Most often these are nuts, popcorn, seeds, raw carrots, grapes, candies, coins, small parts of toys. Sudden onset of stridor in a previously healthy child should always be treated as caused by the presence of a foreign body, until it is excluded in the bronchoscopy. The foreign body of large size can get wedged in the larynx and in combination with reflexive contraction, often occurring in these cases, may lead to severe respiratory failure. It is always direct threat to the child's life. In this situation life-saving treatments may be application of percutaneous tracheotomy or cricothyrotomy.

- External laryngeal trauma in children (Zawadzka-Glos et al. 2013, Oleniacz 2008):

- Injuries of the larynx represent about $1 \%$ of all injuries in children are more common than in adults. The vast majority of damage of the larynx occurs during play or as a result of traffic accidents. Direct manifestation of clinical status does not always correlate with the degree of airway damage of the child. This means that the patient with injury of the larynx showing even minor symptoms to be treated as a patient in critical condition. In these cases, the procedure always applies according to the scheme of first aid used in multiple accidental traumas which main points are: to control breathing disorders and bleeding as well as stabilize the cervical spine.

- Allergic swelling (Zielinska 2010, Lacket al. 2003):

- After a foreign body aspiration, an anaphylactic reaction is the next most important reason explaining the sudden occurrence of respiratory distress symptoms in children. The most common cause of anaphylaxis in children is primarily food, drugs are the second cause and the third one is insect bites. An anaphylactic reaction is a response the body to contact with the allergen. The greatest clinical implications are changes occurring in the respiratory and cardiovascular system. The action of histamine-induced bronchospasm with increasing swelling of the mucosa of the larynx and trachea, causing dyspnoea inspiration - expiration. Vasodilatation leads to a sudden blood pressure drop and consequently to anaphylactic shock. It is accompanied by pallor of skin along with the rising swelling of the face, lips, neck. Rapid assessment of condition of a child with a rapidly developing anaphylactic reaction, if possible interruption of exposure to an allergen, securing airway patency and oxygen therapy, intramuscular adrenaline supply in age-appropriate dose, protection of intravenous access are necessary steps giving the child a chance to survive and transport to the ICU, where it will be provided with highly specialized help.

\section{Symptomatology of increasing obstruction of the upper respiratory tract in children}

Clinical symptoms displayed by a child with upper airway obstruction, regardless of the reason are as follows: (Graczyńska 2007, Szczeklik 2010):

- Increasing dyspnoea, the child suffers from a lack of air, difficulty catching breath despite enhance respiration. The laryngeal dyspnoea resulting from the narrowing of air flow path at this level is an inspiration -expiration. It may occur suddenly and then have a dramatic course. 
- Invalid path of breathing, tachypnea, much larger respiratory rate of a child than the average base of respiratory rate for the age. Breathing becomes shallower, breath elongates and pauses between inspiration and expiration is shortened significantly. Complete closure of the airway causes suffocation (asphyxia).

- Pulling sternum, intercostal space, abdominal and supraclavicular holes results from the mobilization of additional respiratory muscles. The child takes the apparently increased respiratory effort, moving flaps of the nose, the child sweats.

- Wheezing breath (stridor inspiratory, inspiratory - expiratory), with a tight stenosis of the airways at the level of the larynx. During inspiration, you can hear the high, monophonic sound like a whistle, called stridor. This sound is clearly audible, frequently without a stethoscope.

- Coughing is a natural defensive reflex. In the case of suspicion of foreign body aspiration into the respiratory tract you should first encourage your child to cough, because it is an effective way to remove the material obstructing the flow of air through the UA.

- Cyanosis of the skin is a symptom of hypoxic of body tissues and indicates persistent hypoventilation of a child with acute laryngeal dyspnoea.

\section{Principles of conduct in acute dyspnoea in children}

Procedure mainly depends on the cause and degree of airway obstruction as well as the current condition of the child. It should be noted that the patient requires constant monitoring because its condition can suddenly get much worse. Most frequently this is due to the increasing laryngeal oedema or movement of a foreign body. In this study, we focused on the discussion of the principles of first aid in case of complete closure of the air flow through the upper respiratory tract in children, and especially identifying possible ways of unblocking it. In each case of an acute, life-threatening laryngeal dyspnoea coursing with cyanosis, unconsciousness, cardiac arrest without delay there must be perform life-saving treatment unblocking respiratory tract. The most frequently performed in such circumstances are intubation or tracheotomy. In the case where, for various reasons the above steps cannot be performed alternative life-saving treatments are trachea-oesophageal puncture or cricothyrotomy. Tracheopuncture is the introduction through the skin into the lumen of the trachea needle having a diameter of $1.6-1.8 \mathrm{~mm}$. Tracheopuncture performed in the midline beneath the arch cricoid cartilage. Percutaneous (needle) Cricothyrotomy involves puncture of ligament - thyroid cricothyroid and introducing cannula into the lumen of the trachea, through which pressurized respiratory gases (oxygen) are blown. Tracheopuncture and cricothyrotomy needles are ad hoc, temporary life-saving treatments. After accomplishment of them full patency of the airway (intubation, tracheostomy) must be provided, as soon as possible. Child with established cannula must immediately be taken to the hospital. Due to insufficient ventilation after 30 - 45 minutes the hypercapnia and respiratory acidosis occur (Oleniacz 2008, Szreter 2011).

\section{Summary}

Acute laryngeal dyspnoea is a multidisciplinary problem. It requires careful diagnosis of causes and careful observation of a sick child, because the prognosis is always uncertain. Knowledge of the symptoms and causes of upper airway obstruction allows for efficient handling of the child in this dramatic health situation. Sharp course of inspiratory dyspnoea is always life-threatening condition. This requires undertaking by the rescue team immediate action restoring the patency of the upper respiratory tract.

\section{References:}

1. Bailey M. (2003), Naczyniak podgłośniowy. Magazyn Otolaryngologiczny, Supl. IV: 25-26.

2. Baker S., Kelchner L., Weinrich B. et al. (2006), Pediatric laryngotracheal stenosis and airway reconstruction: a review of voice outcomes, assessment, and treatment issues. Journal of Voice, 4: 632-641.

3. Daniel S. (2006), The Upper Airway: Congenital Malformations. Pediatric Respiratory Reviews, 78: 260-263.

4. Graczyńska D. (2007) (red.), Otolaryngologia dziecięca. Medicapress. Bielsko Biała, 355-416.

5. Kwong K., Hoa M., Coticchia J. (2007), Reccurent cro-up presentation, diagnosis and management. Am. J. of Otolarytngology, 28: 401-407.

6. Lack G., Fox D., Golding J. et al. (2003), Factors associated with the development of peanut allergy in childhood. N Engl J Med. 348: 977-985.

7. Maciejewski R., Torres K. (2007), Anatomia czynnościowa - podręcznik dla studentów pielęgniarstwa, fizjoterapii, ratownictwa medycznego, analityki medycznej i dietetyki. Wydawnictwo Czelej, Lublin 
8. Oleniacz T. (2008), Duszność wdechowa u dzieci. Lekarz, 12:59-66.

9. Szczeklik A. (2010) (red.), Choroby wewnętrzne. Medycyna Praktyczna, Kraków.

10. Szenborn L., Pejcz J., Szymański H. i wsp. (2004), Przyczyny ostrej duszności krtaniowej u dzieci - wyniki prospektywnych wieloośrodkowych obserwacji. Przew. Lek., 5:457-462.

11. Szreter T. (2011), Krikotyroidotomia przezskórna. Med. Prakt. Chir., 5: 86-90.

12. Yuen H-W., Kun-Kiaang Tan H., Balakrishnan A. (2006), Synchronous airway lesions and associated anomalie in children with laryngomalacia evaluated with rigid endoscopy. I. J. of Pediatric Otholaryngology, 70: 1779-1784.

13. Zawadzka-Glos L., Jakubowska A., Frackiewicz M. et al. (2013), External laryngeal injuries in children - comparison of diagnostic methods. I. J. of Pediatric Otorhinolaryngology, 77: 1582-1584.

14. Zielińska M. (2010), Postępowanie w wybranych stanach nagłych u dzieci - wstrząs anafilaktyczny. Klin. Pediatr., 5: 5082-5084.

Submitted: 26.08.2014

Accepted: 07.11.2014 